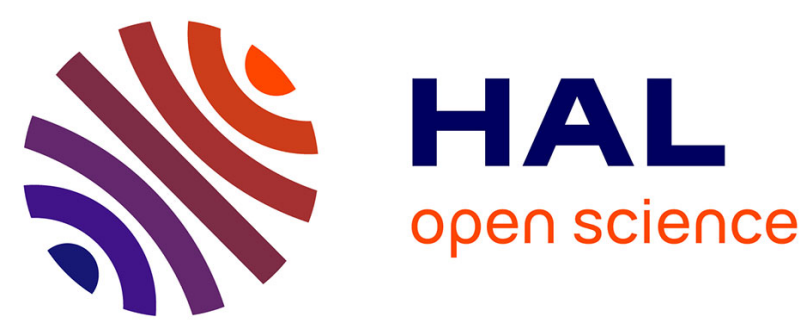

\title{
Sharing wintering grounds does not synchronize annual survival in a high Arctic seabird, the little auk
}

S Descamps, B Merkel, H Strøm, Rémi Choquet, H Steen, Jérôme Fort, M Gavrilo, David Grémillet, D Jakubas, K Jerstad, et al.

\section{- To cite this version:}

S Descamps, B Merkel, H Strøm, Rémi Choquet, H Steen, et al.. Sharing wintering grounds does not synchronize annual survival in a high Arctic seabird, the little auk. Marine Ecology Progress Series, 2021, SEA, 10.3354/meps13400 . hal-03017418

\section{HAL Id: hal-03017418 \\ https://hal.science/hal-03017418}

Submitted on 20 Nov 2020

HAL is a multi-disciplinary open access archive for the deposit and dissemination of scientific research documents, whether they are published or not. The documents may come from teaching and research institutions in France or abroad, or from public or private research centers.
L'archive ouverte pluridisciplinaire HAL, est destinée au dépôt et à la diffusion de documents scientifiques de niveau recherche, publiés ou non, émanant des établissements d'enseignement et de recherche français ou étrangers, des laboratoires publics ou privés. 
$1 \quad$ Sharing wintering grounds does not synchronize annual survival in a high

4 Sébastien Descamps ${ }^{*}, 1$, Benjamin Merkel $^{1}$, Hallvard Strøm ${ }^{1}$, Rémi Choquet ${ }^{2}$, Harald Steen ${ }^{1}$, Jérome

$5 \quad$ Fort $^{3}$, Maria Gavrilo ${ }^{4}$, David Grémillet ${ }^{2}$, Dariusz Jakubas ${ }^{5}$, Kurt Jerstad ${ }^{6}$, Nina J. Karnovsky ${ }^{7}$, Yuri V. Krasnov ${ }^{4}$, Børge Moe ${ }^{8}$, Jorg Welcker ${ }^{9}$ and Katarzyna Wojczulanis-Jakubas ${ }^{5}$ Université Paul-Valéry Montpellier - EPHE, 34293 Montpellier, France Littoral, Environnement et Sociétés (LIENSs), UMR 7266 CNRS - La Rochelle Université, 17000 La Rochelle, France

134 Association Maritime Heritage, Saint Petersburg, Russia

145 University of Gdańsk, Faculty of Biology, Department of Vertebrate Ecology and Zoology, 80-308 15 Gdańsk, Poland

166 Aurebekksveien 61, 4515 Mandal, Norway

177 Pomona College, Department of Biology, Claremont, California, 91711 USA

188 Norwegian Institute for Nature Research, 7034 Trondheim, Norway

199 BioConsult SH, 25813 Husum, Germany

20 Running page head: Little auk winter distribution and survival

$22 *$ Corresponding author

\section{Sébastien Descamps}

24 sebastien.descamps@npolar.no 


\section{ABSTRACT}

27 Sharing the same wintering grounds by avian populations breeding in various areas may

28 synchronize fluctuations in vital rates, which could increase the risk of extinction. Here, by

29 combining multi-colony tracking with long-term capture-recapture data, we studied the winter

30 distribution and annual survival of the most numerous Arctic seabird, the little auk Alle alle. We

31 assessed whether or not little auks from different breeding populations in Svalbard and Franz Josef

32 Land use the same wintering grounds and if this leads to synchronized survival. Our results indicate

33 that birds from the Svalbard colonies shared similar wintering grounds, though differences existed

34 in the proportion of birds from each colony using the different areas. Little auks from Franz Josef

35 Land generally spent the winter in a separate area but some individuals wintered in the Iceland Sea

36 with Svalbard populations. Survival data from three Svalbard colonies collected in 2005-2018

37 indicated that sharing wintering grounds did not synchronize little auk annual survival rates.

38 However, it is clear that the Iceland Sea is an important wintering area for little auks and

39 environmental changes in this area could have widespread impacts on many populations.

41 Key-words: migration, synchrony, Alle alle, non-breeding distribution, geolocator, capture-mark42 recapture 


\section{INTRODUCTION}

44 Knowledge about the migratory connectivity, i.e. the link between breeding and non-breeding areas, (Taylor \& Norris, 2010), is required to understand the degree of dependency among populations on a specific environment or geographic area, and their sensitivity to environmental changes occurring in this area. Sharing the same environment during winter may synchronize fluctuations of distant populations through a so-called Moran effect. This effect corresponds to the synchronization in the dynamics of populations by density-independent factors (like climate) that are correlated across wide regions (Moran 1953, Bjørnstad et al. 1999). and which may increase the risk of extinction (Heino et al. 1997, Palmqvist \& Lundberg 1998, Engen et al. 2005). Moreover, knowledge of migratory connectivity, and more specifically inter-population mixing in the wintering grounds, will help to define appropriate conservation or management units (Webster et al. 2002, Runge et al. 2015). Protecting a specific wintering area will have different effects in the case of low or high inter-population mixing, i.e. if it is used by individuals from only one or from several breeding populations (Finch et al. 2017).

To assess such migratory connectivity and its potential importance for population or species dynamics, it is necessary to (i) assess the winter distribution of several populations of the same species, and (ii) determine whether or not sharing this wintering ground synchronizes the populations' trajectories. Many migratory species are long-lived and their population dynamics and viability are particularly sensitive to changes in adult survival (Saether \& Bakke 2000) and to changes that occur during the non-breeding season (e.g., Gaston 2003, Descamps et al. 2013, Reiertsen et al. 2014). It is therefore especially important to understand the potential relationships between conditions in the wintering grounds and adult survival. Mapping the winter distribution of migratory species has, until recently, been extremely challenging, especially for small species that cannot be equipped with large telemetry devices (Ropert-Coudert \& Wilson 2005). However, the 
development of new technologies in the last three decades and the miniaturization of data loggers and transmitters has led to a large increase in our understanding of migratory species movements (Ropert-Coudert \& Wilson 2005). To link these movements and migratory behaviours to population dynamics, long-term monitoring data of population size and/or vital rates are needed. These data are particularly valuable for Arctic species experiencing rapid and large scale environmental changes (Intergovernmental Panel on Climate Change 2013, AMAP 2017, Descamps et al. 2017), and for whom long-term data are challenging to collect. (Mallory et al. 2018).

Here, we studied the annual survival of the most numerous Arctic seabird, the little auk Alle alle, in relation to its winter distribution. More specifically, using individual tracking data, we mapped the winter distribution of little auks breeding in five Arctic colonies to assess whether or not individuals from different breeding populations use the same wintering grounds. Using longterm (2005-2018) Capture-Mark-Resighting (CMR) data from three of these colonies, we tested the hypothesis that sharing the same wintering ground leads to synchronized survival rates.

\section{MATERIALS AND METHODS}

\subsection{Study sites and little auk life history}

The little auk is a seabird with a single-egg clutch and strong mate and nest fidelity (Stempniewicz 2001). It adopts a life-history strategy typical of long-lived species with a population dynamic highly sensitive to changes in adult survival. As with most seabirds, little auks have a delayed age of first reproduction and do not start breeding before the age of three (unpubl. results). The little auk is zooplanktivorous and during the summer, preferentially forages on high-lipid copepods associated with Arctic waters. Calanus glacialis generally represents the main prey in Svalbard (Węsławski et al. 1999, Harding et al. 2009, Kwasniewski et al. 2010, Jakubas et al. 2012, Hovinen et al. 2014b) while both C. hyperboreus and C. glacialis are the main prey species in Franz Josef 
91 Land (Wesławski et al. 1994, Gremillet et al. 2015). During the non-breeding season, the diet of the little auk is less known but may be based on krill spp., Themisto spp. and capelin Mallotus villosus at least in some parts of its wintering range (Rosing-Asvid et al. 2013a).

We collected tracking data (details below) from five colonies: Kongsfjorden (Svalbard, $\left.78^{\circ} 00^{\prime} \mathrm{N}, 12^{\circ} 24^{\prime} \mathrm{E}\right)$, Isfjorden (Svalbard, $\left.78^{\circ} 14^{\prime} \mathrm{N}, 15^{\circ} 19^{\prime} \mathrm{E}\right)$, Bjørnøya (Svalbard, $\left.74^{\circ} 31^{\prime} \mathrm{N}, 1^{\circ} 01^{\prime} \mathrm{E}\right)$, Hornsund (Svalbard, $77^{\circ} 00^{\prime} \mathrm{N}, 1^{\circ} 33^{\prime} \mathrm{E}$ ) and Franz Josef Land (Russia, 80²0'N, 52 $49^{\prime} \mathrm{E}$; Fig.1). Kongsfjorden and Isfjorden are located in the middle of the west Spitsbergen coast, which is influenced by the warm West Spitsbergen Current (WSC), while Bjørnøya is located in the Barents Sea between the north Norwegian coast and Svalbard. Little auks from these three colonies thus forage in an environment with low Arctic conditions. The Hornsund area is characterized by high Arctic conditions and is typically surrounded by water masses colder than Isfjorden and Kongsfjorden due to the influence of the coastal Sørkapp Current, carrying cold, less saline Arctictype water from the northeast Barents Sea (Swerpel 1985, Jakubas et al. 2013). Franz Josef Land is also characterized by high Arctic environmental conditions (Wesławski et al. 1994).

We collected CMR data in three Svalbard colonies: Kongsfjorden, Isfjorden, and Bjørnøya from 2005 (Isfjorden and Bjørnøya) or 2006 (Kongsfjorden) to 2018.

\subsection{Identification of the wintering grounds}

We identified wintering grounds by deploying light-level geolocators on the little auks (Wilson et al. 1992, Fort et al. 2013). Raw positions obtained by geolocation have a relative high average error, which is usually $\sim 200 \mathrm{~km}$ (Phillips et al. 2004, Lisovski et al. 2012). As such, they are appropriate to answer research questions about large-scale movements and distribution (Lisovski et al., 2012, 2019). The geolocators were mounted on a plastic leg band on tarsus. During the period 2010 to 2017 we deployed more than 524 geolocators in the five study colonies, of which 242 geolocators 
were retrieved between 2011 and 2018 (Table SM1). The available tracking data resulted in 248 annual tracks from 188 individuals (tracking data were not obtained in the same years for all colonies; see details in Table SM1). We used several geolocator models (mk181 from British Antarctic Survey, mk4093 from Biotrack, c65 from Migrate Technology, all from Cambridge, UK), and different light thresholds were used in subsequent processing of the light data (1-16, in arbitrary units or lux). After calibration, we assigned appropriate sun elevation angles $\left(-2.5^{\circ}--4.5^{\circ}\right)$ to the different light thresholds and geolocator models. The tracking data for 2010/11 is part of the study by Fort et al. (2013), and we applied the same calibration process as Fort et al. (2013) for the geolocators retrieved in period 2010-2014. This method is based on plotting estimated latitudes over time using a range of sun elevation angles and selecting the angle that minimized the variance of latitudes around the equinox periods. Geolocators retrieved after 2014 were part of the SEATRACK project (http://www.seapop.no/en/seatrack/) and were calibrated using a slightly different approach (Strøm et al. 2019) that followed the same general principles as described above. When using the approach by Fort et al. (2013) most geolocators were assigned with the same sun elevation angle (representing the best average), while in the latter approach we allowed individual angles for each geolocator/track. This inconsistency has only a limited potential effect on the 131 estimated latitudes and does not affect the conclusions of this study. In order to reduce the influence of inaccurate positions, we used the double smoothing 133 procedure described by Hanssen et al. (2016). Latitudes obtained by geolocation are unreliable 134 around the equinoxes, when day length is constant at all latitudes. In this study, we used positions 135 from winter only, defined as December and January, which are not affected by equinox. 
139 We performed kernel analysis to determine high-density aggregations of little auks during winter,

140 defined as December and January, when birds are assumed to occupy their main wintering range

141 (Fort et al. 2012). To estimate colony-specific little auk distributions during the winter, we

142 calculated individual kernel utilization distributions (UD) for tracked birds on a $25 \times 25 \mathrm{~km}$ grid in

143 an azimuthal equidistant projection centered on $66^{\circ} \mathrm{N}$ and $4^{\circ} \mathrm{W}$. We used the package AdehabitatHR

144 (Calenge 2006) from R version 4.0.0 software ( $\mathrm{R}$ Development Core Team 2016) and a constant

145 smoothing parameter of $50 \mathrm{~km}$. For individuals with more than one year of tracking data, a random

146 year was selected for further analyses to avoid pseudo-replication. We extracted the $75 \%$ kernel

147 contour for each individual, rasterized them (with a value of 1 ) on the same $25 \times 25 \mathrm{~km}$ grid and

148 combined all of these individual raster layers to establish colony-specific winter aggregations. To

149 estimate overall little auk wintering areas across colonies, we summed up all colony-specific raster

150 layers. As sample size differed between colonies (table SM1), we rescaled all rasterized winter

151 distributions to 1 before combining them. Finally, we defined the area of highest-density

152 aggregation of little auks from all investigated colonies as the area encompassed by the $90 \%$

153 quantile. We calculated the proportional use of this area by each colony as the number of individual

$15475 \%$ kernel contours of tracked birds overlapping with this area compared to the total number of

155 tracked individuals, while taking into account the fraction of individuals without positional data due

156 to a lack of twilight events during polar night. We quantified inter-colony overlap in winter

157 distribution using Bhattacharyya's affinity (Fieberg \& Kochanny 2005), which we estimated

158 between colony-specific kernel UDs of all tracked individuals (same parameters as above).

159

160

\subsubsection{Little auk survival modeling}

161 We captured, marked and re-sighted little auks in specific study plots in three colonies

162 (Kongsfjorden, Isfjorden and Bjørnøya), with slightly different methods. We ringed birds with both 
163 steel and plastic color bands, which allowed identification at a distance. We only included in this 164 study those birds captured for the first time as adults (of unknown age). In all three colonies, we 165 carried out fieldwork from approximately mid-June (incubation) to late July (chick-rearing). In 166 Kongsfjorden and Isfjorden, we captured birds using nylon loops deployed on top of random rocks 167 within the study plots, while at Bjørnøya, we captured birds by various methods, including nets at 168 nest entrance and remote snare traps. In total, 781, 592 and 972 adult little auks were ringed in 169 Kongsfjorden, Isfjorden and Bjørnøya, respectively, in the period 2005-2018 (average of 71 new 170 rings/year, range $[6,336]$ in Kongsfjorden, of 46 new rings/year, range $[8,108]$ in Isfjorden, and of 17175 new rings/year, range $[28,132]$ on Bjørnøya). We used the software E-Surge (Choquet et al. 172 2009) to model CMR data to estimate survival rates (Lebreton et al. 1992a), with data from the 173 three colonies combined and defined as three different groups. The method cannot separate 174 permanent emigration from mortality and only estimates apparent survival. However, little auks show a very high colony and nest fidelity (Stempniewicz 2001) and the assumption that apparent survival reflects true survival is robust. We considered both males and females together to estimate 177 little auk adult survival as preliminary analyses indicated no sex-difference in survival. Details 178 about the CMR modelling, model selection procedure and goodness-of-fit tests are given in 179 supplementary material Text SM1.

To assess the synchrony among colonies in little auk survival rate fluctuations, we used two 181 different approaches. First, we compared additive and interactive time-dependent models. 182 Synchronous variation in survival should lead to survival varying in parallel through time among 183 colonies, so that a model with an additive time effect (model $\phi(g+t)$ where $\phi$ represents the survival, $184 \mathrm{~g}$ the group or colony and the time) should be preferred over a model where each colony shows 185 different interannual variation (model $\phi($ g.t)). Second, we considered the survival rates of each 186 colony (of the non-transient group, see details in Text SM1) estimated from time-dependent models 
$\phi(g . t)$ and calculated the mean cross-correlation (which quantifies the synchrony) and associated bootstrap confidence intervals using the mSynch function in the ncf package (Bjørnstad et al. 1999, Bjørnstad 2009) in R software (R Development Core Team 2016).

\section{RESULTS}

\subsection{Little auk wintering distribution}

During the winter months (December-January), little auks from Svalbard and Franz Josef Land dispersed to the area between eastern Canada and the Barents Sea (Fig. 1). Birds from Kongsfjorden and Isfjorden were mostly distributed in eastern Canada (Labrador Sea), south Greenland and in the Iceland Sea (Fig1). Kongsfjorden birds, however, migrated to the mouth of Hudson Strait and fewer Kongsfjorden birds than Isfjorden ones went to southeast Greenland (Fig. 1). Birds from Hornsund and Bjørnøya were mostly present in the Iceland Sea and around the southern tip of Greenland (Fig. 1). Birds from Franz Josef Land stayed mainly in the Barents Sea and in the Iceland Sea (Fig. 1). Despite some differences among colonies in their winter distribution, the area in the Iceland Sea was used by birds from all study sites in December and January (Fig. 2a). Approximately half of the tracked birds from Hornsund and Bjørnøya and 20-30\% of those from Kongsfjorden and Isfjorden spent the winter in this area (Fig. 2b). The proportion of Franz Josef Land birds wintering in the Iceland Sea was lower (approximately 10\%, Fig. 2b). Most of the Franz Josef Land population wintered in the Barents Sea and/or at high latitudes above the Arctic circle. Indeed, the majority of the light data from Franz Josef land little auks did not include any twilight events (Fig. 2c) which implies that the birds were staying at high latitudes where night was permanent. The proportion of birds using the Iceland Sea throughout the winter followed a similar trajectory for all colonies. The number of birds there increased until late November, was the highest in December/January and then decreased from late January onwards, when birds most likely started their spring migration (Fig. $2 b$ and Fig. SM2). 
When considering the entire winter distribution for each colony (as colony-specific kernel UD

213 in December/January), we found that the overlap was high among all Svalbard colonies (i.e.

214 Bhattacharyya's affinity $>0.6$ ) and not a function of the distance between these colonies (Table 1).

215 This overlap was smaller between Franz Josef Land and Svalbard colonies (Bhattacharyya's affinity

$216<0.6$; Table 1). Given that the majority of tracked individuals from Franz Josef Land spent the

217 winter where there is continuous polar night and thus where birds' positions cannot be estimated

218 (Fig. SM1), the overlap between Svalbard colonies and Franz Josef Land is likely overestimated.

\subsection{Synchrony in survival fluctuations}

The average survival of little auks was different among colonies (model $\phi_{\mathrm{g}+\mathrm{t}}$ was preferred over model $\phi_{\mathrm{t}}$; Table 2), being slightly higher in Isfjorden. (Isfjorden: 0.80, 95\% CI: [0.77, 0.83]; Kongsfjorden: 0.85, 95\% CI: [0.82, 0.88] and 0Bjørnøya: 0.81, 95\% CI: [0.79, 0.83]). Little auk survival showed significant inter-annual fluctuations (Fig. 1; Table SM2) and a model constraining survival to vary in parallel among colonies was preferred (i.e. lower AIC for the additive model $\phi_{\mathrm{g}+\mathrm{t}}$ than for model $\phi_{\mathrm{g} . \mathrm{t}}$; Table 2$)$. However, this mostly reflects the rather large confidence intervals around survival estimates, rather than the variation in their means (which are not parallel, especially for Kongsfjorden). This result also seems mostly driven by Isfjorden and Bjørnøya, which have more similar inter-annual variations as compared to Kongsfjorden (Fig. 2). This is supported by the fact that a model constraining only Isfjorden and Bjørnøya survival to vary in 231 parallel (i.e. model $\phi_{\mathrm{g}(1) \cdot \mathrm{t}+\mathrm{g}(2,3)+\mathrm{t})}$ had a better fit than models constraining only Kongsfjorden and Bjørnøya, or Kongsfjorden and Isfjorden to vary in parallel (Table 2). The cross-correlation coefficient between the annual survival from these three colonies

234 (survival rates estimated from model $\phi_{\text {g.t }}$ ) indicates that the overall synchrony was weak and nonsignificant (cross-correlation $=0.10,95 \% \mathrm{CI}:[-0.25,0.30])$. This coefficient is not taking the 
uncertainty around the means (i.e. confidence intervals) into account and only reflects the lack of synchrony in the variations of the mean annual survival rates (Fig.2).

\section{DISCUSSION}

240 By tracking little auks from five different colonies in the European Arctic, we found that birds 241 breeding in Svalbard had a similar winter distribution, though some differences exist (Fig. SM1). 242 Birds from Franz Josef Land differed more markedly and mostly stayed in the Barents Sea during 243 winter. The Barents Sea is rapidly changing and has become increasingly suitable habitat for 244 wintering little auks (Clairbaux et al. 2019). However the area used by Franz Josef Land little auks has been mostly ice-free in winter, for at least the last 150 years (Shapiro et al. 2006). Therefore, the current winter distribution of little auks in the Barents Sea may not represent contemporary changes in the recent rapid loss of sea-ice (e.g. Parkinson et al. 1999, Li et al. 2017). Despite these differences among colonies in their winter distribution, we identified a key wintering area in the Iceland Sea, where some birds from all of Svalbard and Franz Josef Land colonies spent the winter months. These results confirm that little auks from the European Arctic share, to varying degrees, their wintering grounds. The proportion of tracked birds spending the winter north of Iceland varied among colonies but was as high as 50-60\% for birds breeding in Bjørnøya and Hornsund. Svalbard and Franz Josef Land host more than 1.5 million breeding pairs of little auks (Keslinka et al. 2019), indicating that a huge number of little auks likely spend the winter months in this area (though this still represents a small proportion of the entire Atlantic population estimated at several 10s of million pairs, del Hoyo et al. 1996). The importance of the Iceland Sea during winter for little auks breeding in Svalbard and East Greenland had already been suggested (Fort et al. 2013). Our results corroborate this finding by showing that even little auks from the Franz Josef Land population utilize this area. The number of birds from Svalbard and Russia wintering there was highest in 
December-January, and then gradually decreased from February onwards. Other Arctic seabirds spend the winter in this region as well, such as Brünnich's guillemots Uria lomvia from Bjørnøya (Frederiksen et al. 2016) and other alcid species breeding in Iceland (Linnebjerg et al. 2018). The Iceland Sea can therefore be considered as a hotspot for wintering Arctic seabirds, with hotspot defined as "an area where high abundances of species overlap in space and time" (Davoren 2007).

This hotspot is located between Jan Mayen and Iceland over the Jan Mayen ridge and is characterized by complex oceanic currents (Astthorsson et al. 2007, Mork et al. 2014). This ridge separates the warm Atlantic waters in the Norwegian Sea from the cold Arctic ones in the Iceland Sea. As with most oceanic front systems, it is associated with high marine productivity and densities of zooplankton (e.g. Wiborg 1955, Trudnowska et al. 2012) and thus potentially high prey availability for little auks. The winter diet of little auks is poorly known but krill (Euphausiacea) may represent an important prey in parts of the wintering range (Fort et al. 2010, Rosing-Asvid et al. 2013b). Recent studies have also suggested that the winter distribution of little auks is linked to the distribution of the copepod Calanus finnmarchicus (Fort et al. 2012, Amélineau et al. 2018). These species are among the most abundant zooplankton in the Iceland Sea, though the overall plankton abundance declines in winter (Gislason \& Silva 2012). However, despite such a seasonal decline, zooplankton biomass in the core wintering areas of little auks, remains relatively high, at least in some years (Fig. SM3).

Capture-recapture data were available from three of the five study colonies to determine the level of synchrony in their survival rates. The average survival in the three colonies was similar 280 (approx. 0.80), though slightly higher in Isfjorden. This is also comparable with the survival of 281 Greenlandic little auks (Amélineau et al. 2019) and with other alcids of similar size and life-history 282 (i.e. single-egg layers)(e.g., average adult survival of 0.83 for the Marbled murrelet Brachyramphus marmoratus, Cam et al. 2003, of 0.80 for the Kittlitz's murrelet Brachyramphus brevirostris, 
Kissling et al. 2015). The survival of Svalbard little auks showed high inter-annual fluctuations, as observed in previous studies both in Svalbard and Greenland (Hovinen et al. 2014a, Amélineau et al. 2019). The magnitude of these fluctuations is surprising (and thus far unexplained) for a species in which adult survival has the largest influence on the population growth rate (Stearns \& Kawecki 1994). However, such large inter-annual fluctuations in survival seem to be common in alcids and have been observed in Ancient Murrelets Synthliboramphus antiquus (Gaston \& Descamps 2011), least auklets Aethia pusilla (Jones et al. 2002), Brünnich's guillemots Uria lomvia (Fluhr et al. 2017) and Atlantic puffins Fratercula arctica (Sandvik et al. 2005). winter distribution. The third Svalbard colony (Bjørnøya) differed slightly with the majority of birds staying north of Iceland or around the southern tip of Greenland and with very few birds wintering along the Labrador coast. The synchrony in survival rates did not reflect these patterns in wintering areas. Indeed, Bjørnøya and Isfjorden had more similar survival fluctuations throughout the study period while survival fluctuations from Kongsfjorden differed markedly. Even if a model with parallel survival for the three colonies was preferred, this was likely driven by the large confidence intervals around the mean survival rates and overall, the synchrony in these mean survival rates was very low. This shows that sharing part of the same wintering grounds was insufficient to synchronize little auks' average annual survival rates. Several non-exclusive explanations can be proposed. First, the survival of little auks may have been more affected by what happened outside of the winter period (see for example Schaub et al. 2005 where survival of white 304 storks was mostly determined by conditions at one staging area used in the autumn). For instance, 305 little auks may be particularly vulnerable to environmental constraints during their flightless post306 breeding moulting period, for which contrasting distributions between Svalbard colonies were suggested (Fort et al. 2013). It has also been shown, though based on a very short time-series, that 
an increase in the summer sea surface temperature resulted in a decrease in survival rates of adult

309 little auks at some Svalbard colonies, probably through impaired nutritional status during the

310 breeding season (Hovinen et al. 2014a). A study performed in one Greenland colony during a

311 breeding season with relatively poor foraging conditions (reflected in elevated levels of

312 corticosterone) found that little auk parents ended the reproductive season with low body mass and

313 suffered increased post-breeding mortality (Harding et al. 2011). These results stress the importance

314 of conditions experienced during the summer (i.e. breeding) period in driving little auk survival.

315 Assessing the overlap in little auk distribution outside the winter period (i.e. during the breeding

316 season, molting period and migration) would be needed but presents important challenges. In

317 particular, constant darkness and/or daylight for part of the year at high latitudes combined with the

318 difficulty of estimating bird positions around the equinoxes prevent the use of light data to map

319 little auk distribution during a large part of their annual cycle. Using different tracking devices

320 and/or supplementing the light data with other sources of information (see details in Merkel et al.

3212016 for example) would be necessary. Second, even if little auks shared the same space on a large

322 scale during winter, birds from different breeding grounds may segregate at a finer scale (temporal 323 or spatial) and use different environments and potentially food sources. To test this hypothesis, fine324 scale tracking data, potentially combined with diet information from wintering little auks, would be 325 necessary.

\section{Conclusion}

327 Our study identified a common wintering ground used by little auks from both Svalbard and Franz 328 Josef Land (Russian Arctic). This result has important management and conservation implications. 329 Even though sharing part of the wintering grounds did not lead to synchronized annual survival 330 during our study, what happens at these wintering grounds, and in particular in this common area 331 north of Iceland, may still have an effect on their population dynamics. Indeed, by using the same 
332 wintering grounds, populations of little auks are likely to experience similar environmental

333 conditions during this season and are thus, to some extent, subject to the same environmental

334 drivers of population change. Any change in this region, like an increase in shipping or drilling

335 activities, modifications to resource availability or climate conditions, could thus have a widespread

336 effect on little auks breeding throughout the European Arctic. 


\section{Acknowledgements}

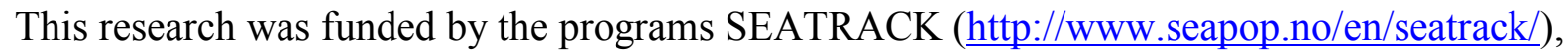

SEAPOP (http://www.seapop.no/en/) and MOSJ (http://www.mosj.no/en/). We thank all the field workers that helped in collecting the data and in particular Delphin Ruché, Saga Svavarsdóttir, Iñigo López Sarasa, Antonio Vilches, Charlotte Lassen, Bart Peeters, Ireen Vieweg, Coline Marciau, and Benjamin Metzger for Kongsfjorden and Isfjorden fieldwork and Madeleine Stigner for Hornsund fieldwork.

\section{Literature cited}

AMAP (2017) Snow, Water, Ice and Permafrost in the Arctic (SWIPA). In, Oslo, Norway Amélineau F, Fort J, Mathewson P, Speirs D, Courbin N, Perret S, Porter W, Wilson R, Grémillet D (2018) Energyscapes and prey fields shape a North Atlantic seabird wintering hotspot under climate change. Royal Society open science 5:171883

Amélineau F, Grémillet D, Harding AM, Walkusz W, Choquet R, Fort J (2019) Arctic climate change and pollution impact little auk foraging and fitness across a decade. Scientific reports 9:1014

Astthorsson OS, Gislason A, Jonsson S (2007) Climate variability and the Icelandic marine ecosystem. Deep Sea Research Part II: Topical Studies in Oceanography 54:2456-2477

Bjørnstad ON (2009) ncf: spatial nonparametric covariance functions. R package version 1.1-3. http://CRAN.R-project.org/package=ncf.

Bjørnstad ON, Ims RA, Lambin X (1999) Spatial population dynamics: analyzing patterns and processes of population synchrony. Trends Ecol Evol 14:427-432

Calenge C (2006) The package "adehabitat" for the R software: a tool for the analysis of space and habitat use by animals. Ecol Modell 197:516-519

Cam E, Lougheed L, Bradley R, Cooke F (2003) Demographic assessment of a marbled murrelet population from capture-recapture data. Conservation Biology 17:1118-1126

Choquet R, Rouan L, Pradel R (2009) Program E-SURGE: a software application for fitting Multievent models. In: Thomson DL, Cooch EG, Conroy MJ (eds) Environmental and Ecological Statistics, Book 3

Clairbaux M, Fort J, Mathewson P, Porter W, Strøm H, Grémillet D (2019) Climate change could overturn bird migration: Transarctic flights and high-latitude residency in a sea ice free Arctic. Scientific Reports 9:1-13

Davoren GK (2007) Effects of gill-net fishing on marine birds in a biological hotspot in the Northwest Atlantic. Conservation Biology 21:1032-1045

del Hoyo J, Elliott A, Sargatal J (1996) Handbook of the Birds of the World, vol. 3: Hoatzin to Auks., Vol. Lynx Edicions, Barcelona, Spain

Descamps S, Aars J, Fuglei E, Kovacs KM, Lydersen C, Pavlova O, Pedersen AO, Ravolainen V, 
Strøm H (2017) Climate change impacts on wildlife in a High Arctic archipelago - Svalbard, Norway. Glob Change Biol 23:490-502

Descamps S, Strøm H, Steen H (2013) Decline of an arctic top predator: synchrony in colony size fluctuations, risk of extinction and the subpolar gyre. Oecologia 173:1271-1282

Engen S, Lande R, Saether BE, Bregnballe T (2005) Estimating the pattern of synchrony in fluctuating populations. J Anim Ecol 74:601-611

Fieberg J, Kochanny CO (2005) Quantifying home-range overlap: the importance of the utilization distribution. The Journal of Wildlife Management 69:1346-1359

Finch T, Butler SJ, Franco AM, Cresswell W (2017) Low migratory connectivity is common in long-distance migrant birds. J Anim Ecol 86:662-673

Fluhr J, Strøm H, Pradel R, Duriez O, Beaugrand G, Descamps S (2017) Weakening of the subpolar gyre as a key driver of North Atlantic seabird demography: a case study with Brünnich's guillemots in Svalbard. Mar Ecol Prog Ser 563:1-11

Fort J, Beaugrand G, Grémillet D, Phillips RA (2012) Biologging, remotely-sensed oceanography and the continuous plankton recorder reveal the environmental determinants of a seabird wintering hotspot. PloS one 7:e41194

Fort J, Cherel Y, Harding AM, Egevang C, Steen H, Kuntz G, Porter WP, Grémillet D (2010) The feeding ecology of little auks raises questions about winter zooplankton stocks in North Atlantic surface waters. Biol Lett 6:682-684

Fort J, Moe B, Strom H, Gremillet D, Welcker J, Schultner J, Jerstad K, Johansen KL, Phillips RA, Mosbech A (2013) Multicolony tracking reveals potential threats to little auks wintering in the North Atlantic from marine pollution and shrinking sea ice cover. Divers Distrib 19:1322-1332

Frederiksen M, Descamps S, Erikstad KE, Gaston AJ, Gilchrist HG, Grémillet D, Johansen KL, Kolbeinsson Y, Linnebjerg JF, Mallory ML (2016) Migration and wintering of a declining seabird, the thick-billed murre Uria lomvia, on an ocean basin scale: Conservation implications. Biol Conserv 200:26-35

Gaston A, Descamps S (2011) Population change in a marine bird colony is driven by changes in recruitment. Avian Conservation and Ecology 6

Gaston AJ (2003) Synchronous fluctuations of thick-billed murre (Uria lomvia) colonies in the eastern Canadian arctic suggest population regulation in winter. The Auk 120:362-370

Gislason A, Silva T (2012) Abundance, composition, and development of zooplankton in the Subarctic Iceland Sea in 2006, 2007, and 2008. ICES J Mar Sci 69:1263-1276

Gremillet D, Fort J, Amelineau F, Zakharova E, Le Bot T, Sala E, Gavrilo M (2015) Arctic warming: nonlinear impacts of sea-ice and glacier melt on seabird foraging. Glob Change Biol 21:1116-1123

Hanssen SA, Gabrielsen GW, Bustnes JO, Bråthen VS, Skottene E, Fenstad AA, Strøm H, Bakken V, Phillips RA, Moe B (2016) Migration strategies of common eiders from Svalbard: implications for bilateral conservation management. Polar Biol 39:2179-2188

Harding AMA, Egevang C, Walkusz W, Merkel F, Blanc S, Grémillet D (2009) Estimating prey capture rates of a planktivorous seabird, the little auk (Alle alle), using diet, diving behaviour, and energy consumption. Polar Biol 32:785-796

Heino M, Kaitala V, Ranta E, Lindstrom J (1997) Synchronous dynamics and rates of extinction in spatially structured populations. Proc R Soc Lond B 264:481-486

Hovinen JEH, Welcker J, Descamps S, Strøm H, Jerstad K, Berge J, Steen H (2014a) Climate warming decreases the survival of the little auk (Alle alle), a high Arctic avian predator. Ecol and Evol 4:3127-3138

Hovinen JEH, Wojczulanis-Jakubas K, Jakubas D, Hop H, Berge J, Kidawa D, Karnovsky NJ, 
Steen H (2014b) Fledging success of little auks in the high Arctic: do provisioning rates and the quality of foraging grounds matter? Polar Biol 37:665-674

Intergovernmental Panel on Climate Change (2013) Climate Change 2013: The Physical Science Basis. Working Group II Contribution to the IPCC 5th Assessment Report, Vol. http://www.ipcc.ch/report/ar5/wg2/

Jakubas D, Iliszko L, Wojczulanis-Jakubas K, Stempniewicz L (2012) Foraging by little auks in the distant marginal sea ice zone during the chick-rearing period. Polar Biol 35:73-81

Jakubas D, Trudnowska E, Wojczulanis-Jakubas K, Iliszko L, Kidawa D, Darecki M, BłachowiakSamołyk K, Stempniewicz L (2013) Foraging closer to the colony leads to faster growth in little auks. Mar Ecol Prog Ser 489:263-278

Jones IL, Hunter FM, Robertson GJ (2002) Annual adult survival of Least Auklets (Aves, Alcidae) varies with large-scale climatic conditions of the North Pacific Ocean. Oecologia 133:38-44

Keslinka LK, Wojczulanis-Jakubas K, Jakubas D, Neubauer G (2019) Determinants of the little auk (Alle alle) breeding colony location and size in W and NW coast of Spitsbergen. PloS One 14:e0212668

Kissling ML, Lukacs PM, Gende SM, Lewis SB (2015) Multi-state mark-recapture model to estimate survival of a dispersed-nesting seabird, the Kittlitz's Murrelet. The Journal of Wildlife Management 79:20-30

Konyukhov N (2002) Possible ways of spreading and evolution of Alcids. Biology Bulletin of the Russian Academy of Sciences 29:447-454

Kwasniewski S, Gluchowska M, Jakubas D, Wojczulanis-Jakubas K, Walkusz W, Karnovsky N, Blachowiak-Samolyk K, Cisek M, Stempniewicz L (2010) The impact of different hydrographic conditions and zooplankton communities on provisioning Little Auks along the West coast of Spitsbergen. Prog Oceanogr 87:72-82

Lebreton J-D, Burnham KP, Clobert J, Anderson DR (1992a) Modeling survival and testing biological hypotheses using marked animals: a unified approach with case studies. Ecol Monogr 62:67-118

Lebreton JD, Burnham KP, Clobert J, Anderson DR (1992b) Modeling survival and testing biological hypotheses using marked animals: a unified approach with case studies. Ecol Monogr 62:67-118

Li D, Zhang R, Knutson TR (2017) On the discrepancy between observed and CMIP5 multi-model simulated Barents Sea winter sea ice decline. Nature Communications 8:1-7

Linnebjerg JF, Frederiksen M, Kolbeinsson Y, Snaethórsson AÖ, Thórisson B, Thórarinsson TL (2018) Non-breeding areas of three sympatric auk species breeding in three Icelandic colonies. Polar Biol 41:1951-1961

Lisovski S, Hewson CM, Klaassen RH, Korner-Nievergelt F, Kristensen MW, Hahn S (2012) Geolocation by light: accuracy and precision affected by environmental factors. Meth Ecol Evol 3:603-612

Mallory ML, Gilchrist HG, Janssen M, Major HL, Merkel F, Provencher JF, Strøm H (2018) Financial costs of conducting science in the Arctic: examples from seabird research. Arctic Science 4:624-633

Merkel B, Phillips RA, Descamps S, Yoccoz NG, Moe B, Strøm H (2016) A probabilistic algorithm to process geolocation data. Movement Ecology 4:26

Moran PAP (1953) The statistical analysis of the Canadian lynx cycle. II. Synchronization and meteorology. Aust J Zool 1:291-298

Mork KA, Drinkwater KF, Jónsson S, Valdimarsson H, Ostrowski M (2014) Water mass exchanges between the Norwegian and Iceland seas over the Jan Mayen Ridge using in-situ current measurements. Journal of Marine Systems 139:227-240 
Palmqvist E, Lundberg P (1998) Population extinctions in correlated environments. Oikos 83:359367

Parkinson CL, Cavalieri DJ, Gloersen P, Zwally HJ, Comiso JC (1999) Arctic sea ice extents, areas, and trends, 1978-1996. Journal of Geophysical Research: Oceans 104:20837-20856

Pereira SL, Baker AJ (2008) DNA evidence for a Paleocene origin of the Alcidae (Aves: Charadriiformes) in the Pacific and multiple dispersals across northern oceans. Molecular phylogenetics and evolution 46:430-445

Phillips RA, Silk JRD, Croxall JP, Afanasyev V, Briggs DR (2004) Accuracy of geolocation estimates for flying seabirds. Mar Ecol Prog Ser 266:265-272

R Development Core Team (2016) R: a language and environment for statistical computing. In. R Foundation for Statistical Computing, Vienna, Austria. http://www.R-project.org/.

Reiertsen TK, Erikstad KE, Anker-Nilssen T, Barrett RT, Boulinier T, Frederiksen M, GonzalezSolis J, Gremillet D, Johns D, Moe B, Ponchon A, Skern-Mauritzen M, Sandvik H, Yoccoz NG (2014) Prey density in non-breeding areas affects adult survival of black-legged kittiwakes Rissa tridactyla. Mar Ecol Prog Ser 509:289-+

Ropert-Coudert Y, Wilson RP (2005) Trends and perspectives in animal-attached remote sensing. Frontiers in Ecology and Evolution 3:437-444

Rosing-Asvid A, Hedeholm R, Arendt K, Fort J, Robertson G (2013a) Winter diet of the little auk (Alle alle) in the Northwest Atlantic. Polar Biology 36:1601-1608

Rosing-Asvid A, Hedeholm R, Arendt K, Fort J, Robertson G (2013b) Winter diet of the little auk (Alle alle) in the Northwest Atlantic. Polar Biol 36:1601-1608

Runge CA, Watson JE, Butchart SH, Hanson JO, Possingham HP, Fuller RA (2015) Protected areas and global conservation of migratory birds. Science 350:1255-1258

Saether BE, Bakke O (2000) Avian life history variation and contribution of demographic traits to the population growth rate. Ecology 81:642-653

Sandvik H, Erikstad KE, Barrett RT, Yoccoz NG (2005) The effect of climate on adult survival in five species of North Atlantic seabirds. J Anim Ecol 74:817-831

Schaub M, Kania W, Köppen U (2005) Variation of primary production during winter induces synchrony in survival rates in migratory white storks Ciconia ciconia. J Anim Ecol 74:656666

Shapiro I, Colony R, Vinje T (2006) April sea ice extent in the Barents Sea, 1850-2001. Polar Res 22:5-10

Stearns SC, Kawecki TJ (1994) Fitness sensitivity and the canalization of life-history traits. Evolution 48:1438-1450

Stempniewicz L (2001) Alle alle little auk. In: BWP Update The Journal of the Birds of the Western Palearctic Book 3. Oxford University Press., Oxford

Strøm H, Helgason HH, Bråthen VS, Descamps S, Ekker M, Fauchald P, Merkel B, Moe B, Tarroux A (2019) Large-scale tracking of seabirds in the Northeast-Atlantic 2014-2018 Final report from SEATRACK phase I. . In: Norsk Polarinstitutt (ed) Rapportserie (Forthcoming)

Swerpel S (1985) The Hornsund fjord: water masses. Polish Polar research 475:96

Trudnowska E, Szczucka J, Hoppe L, Boehnke R, Hop H, Blachowiak-Samolyk K (2012) Multidimensional zooplankton observations on the northern West Spitsbergen Shelf. Journal of Marine Systems 98:18-25

Webster MS, Marra PP, Haig SM, Bensch S, Holmes RT (2002) Links between worlds: unraveling migratory connectivity. Trends Ecol Evol 17:76-83

Wesławski J, Stempniewicz L, Galaktionov K (1994) The food and feeding of little auk from Franz Josef Land. Polar Res 13:173-181 
519 Węsławski J, Stempniewicz L, Mehlum F, Kwaśniewski S (1999) Summer feeding strategy of the $520 \quad$ little auk (Alle alle) from Bjørnøya, Barents Sea. Polar Biol 21:129-134

521 Wiborg KF (1955) Zooplankton in relation to hydrography in the Norwegian Sea. In: Report on Norwegian Fishery and Marine Investigations, Book XI

Wilson RP, Ducamp J, Rees WG, Culik BM, Niekamp K (1992) Estimation of location: global coverage using light intensity. In: Priede IM, Swift SM (eds) Wildlife telemetry: remote monitoring and tracking of animals. Ellis Horward, Chichester 
529 Table 1. Overlap in the winter distribution of Svalbard and Franz Josef Land little auks. The distribution for 530 each colony is based on the months of December and January and was assessed as kernel UD. The overlap 531 was calculated using the Bhattacharyya's affinity index (from $0=$ no overlap to $1=i d e n t i c a l$ distribution; 532 see Methods for details). Distances between colonies (in $\mathrm{km}$ ) are indicated in the lower part of the table 533 (gray area).

534

\begin{tabular}{c|ccccc} 
Colony & Franz Josef & Kongsfjorden & Isfjorden & Hornsund & Bjørnøya \\
& Land & & & & \\
\hline Franz Josef Land & - & 0.32 & 0.35 & 0.51 & 0.48 \\
Kongsfjorden & 795 & - & 0.72 & 0.66 & 0.65 \\
Isfjorden & 769 & 103 & - & 0.80 & 0.73 \\
Hornsund & 851 & 227 & 140 & - & 0.90 \\
Bjørnøya & 993 & 523 & 430 & 296 & -
\end{tabular}


537 Table 2. Synchrony in the survival of little auks breeding at Isfjorden, Kongsfjorden and Bjørnøya. Subscript

538 " $g$ " represents the colony (i.e. $g(1)$ represents Kongsfjorden, $g(2)$ Isfjorden and $g(3)$ Bjørnøya) and " $t$ " the

539 time dependence. The QAIC values have been calculated using an overdispersion parameter $\hat{\boldsymbol{c}}=\mathbf{1} . \mathbf{8 4}$.

$540 \triangle Q A I C$ corresponds to the difference between the QAIC of a given model and the lowest QAIC among the

541 different models considered. Np represents the number of identifiable parameters and Dev the deviance. The 542 survival $\phi$ represents the survival of the non-transient birds (age-class 2). Survival of age class 1 has been 543 modeled as time-dependent with a multiplicative colony/group effect (see Table SM1). Recapture rates have 544 been modelled as colony- and time-dependent with an additive trap-dependence (see table SMI and 545 methods).

546

\begin{tabular}{c|cccc} 
Model & $N p$ & Dev & QAIC & AQAIC \\
\hline$\phi_{g . t}$ & 110 & 13231.72 & 7411.15 & 17.73 \\
$\phi_{g+t}$ & 92 & $\mathbf{1 3 2 6 5 . 3 3 6}$ & $\mathbf{7 3 9 3 . 4 2}$ & $\mathbf{0 . 0 0}$ \\
$\phi_{t}$ & 90 & 13281.75 & 7398.34 & 4.92 \\
$\phi_{g}$ & 81 & 13335.76 & 7409.70 & 16.28 \\
$\phi_{i}$ & 79 & 13347.02 & 7411.82 & 18.40 \\
$\phi_{g(1) . t+[g(2,3)+t]}$ & 101 & 13243.11 & 7399.34 & 5.92 \\
$\phi_{g(2) . t+[g(1,3)+t]}$ & 102 & 13252.83 & 7406.63 & 13.21 \\
$\phi_{g(3) . t+[g(1,2)+t]}$ & 101 & 13247.98 & 7403.99 & 10.57 \\
\hline
\end{tabular}



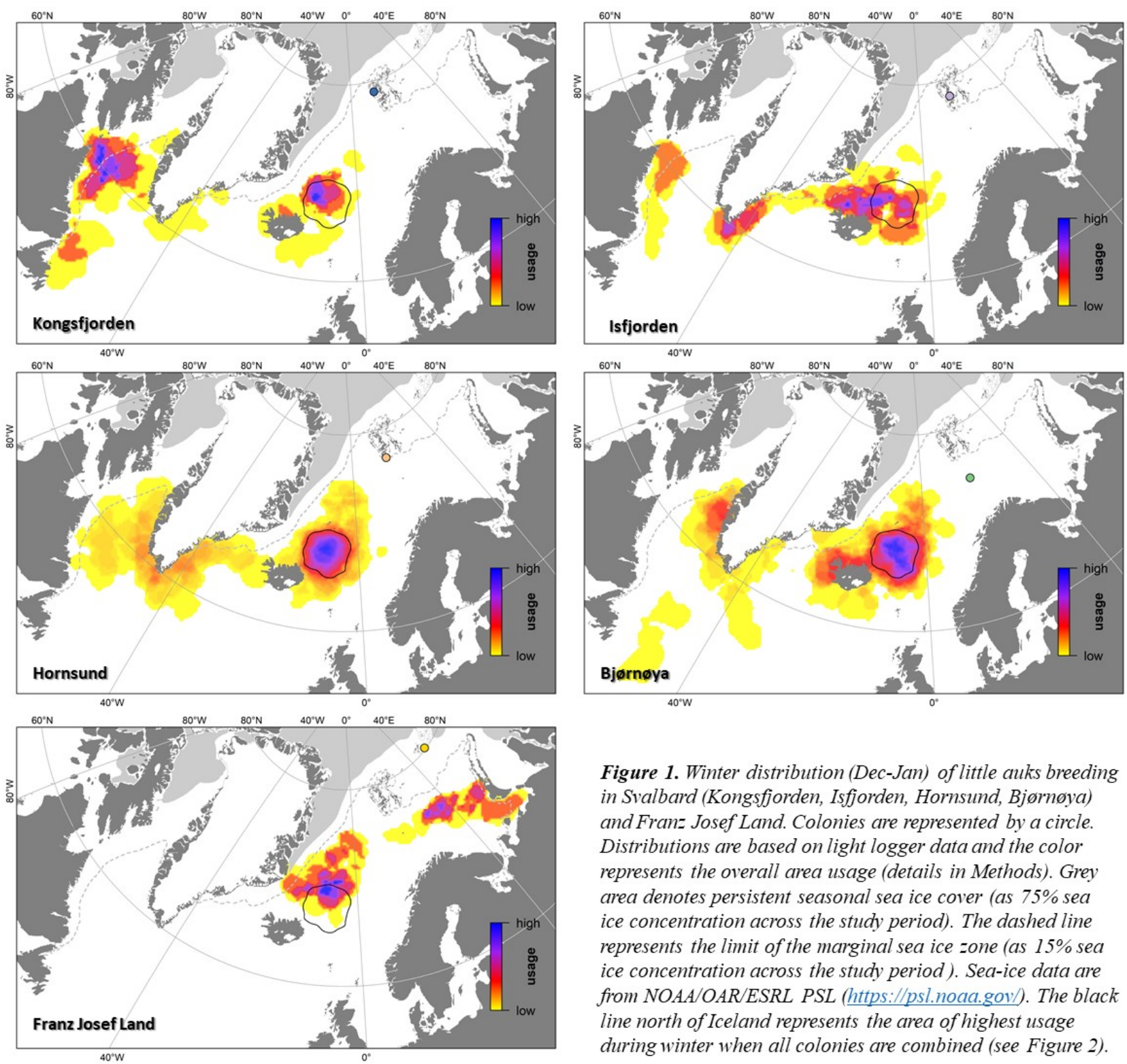

Figure 1. Winter distribution (Dec-Jan) of little auks breeding in Svalbard (Kongsfjorden, Isfjorden, Hornsund, Bjørnøya) and Franz Josef Land. Colonies are represented by a circle. Distributions are based on light logger data and the color represents the overall area usage (details in Methods). Grey area denotes persistent seasonal sea ice cover (as $75 \%$ sea ice concentration across the study period). The dashed line represents the limit of the marginal sea ice zone (as 15\% sea ice concentration across the study period). Sea-ice data are from NOAA/OAR/ESRL PSL (https://psl.noaa.gov/). The black line north of Iceland represents the area of highest usage during winter when all colonies are combined (see Figure 2). 
550 


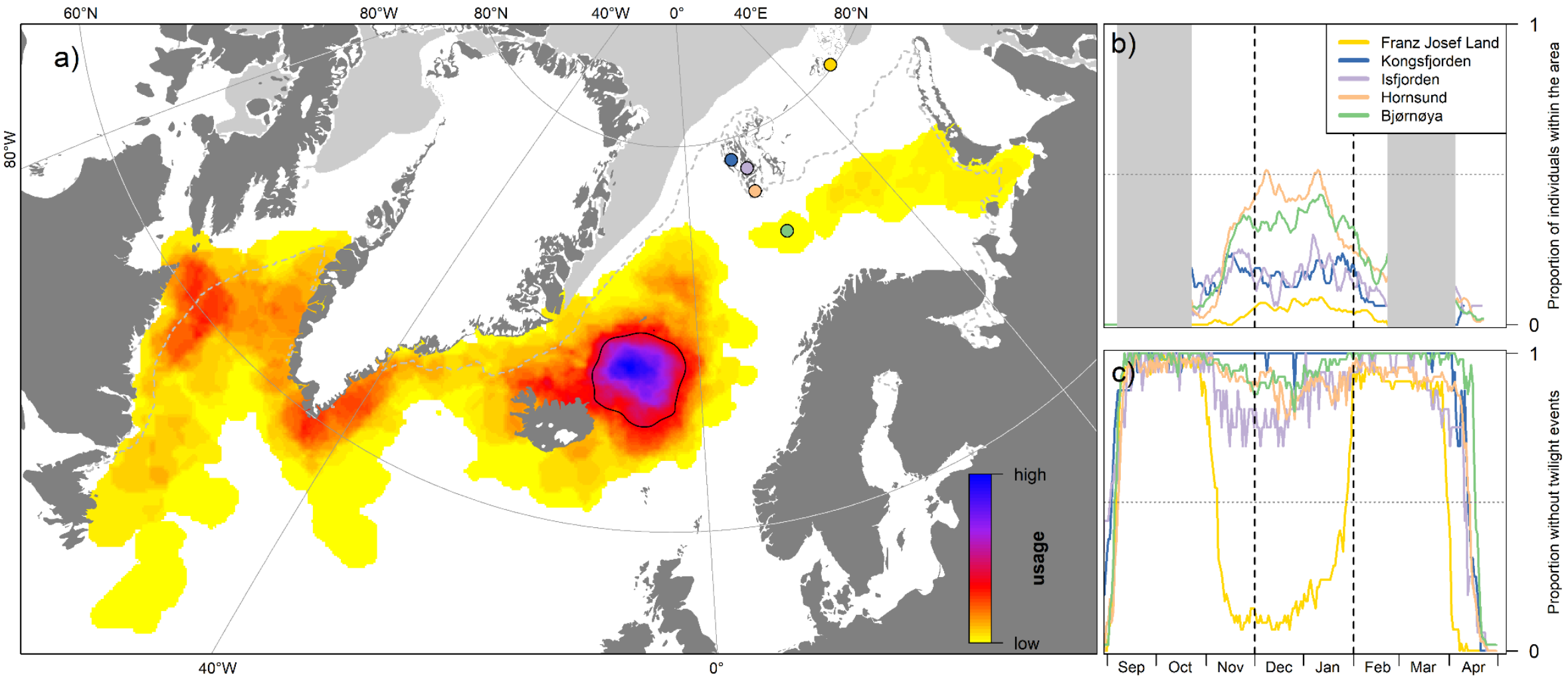

Figure 2. Winter distribution of little auks breeding in Svalbard (Kongsfjorden, blue circle; Isfjorden, purple circle; Hornsund, orange circle; Bjørnøya, green circle) and Franz Josef Land (yellow circle). Distribution is based on 188 little auks tracked throughout the year with light loggers (details in Methods). Panel (a) represents the winter distribution of little auks in Dec-Jan. The colour represents the overall area usage (details in Methods). Grey area denotes persistent seasonal sea ice cover (as $75 \%$ sea ice concentration across the study period). The dashed line represents the limit of the marginal sea ice zone (as $15 \%$ sea ice concentration across the study period). Sea-ice data are from NOAA/OAR/ESRL PSL (https://psl.noaa.gov/). Panel (b) shows the proportion of individuals from each colony present in the area of highest usage north of Iceland during winter (area delineated with a black line in panel (a)); grey areas in the graph represent equinox periods. Panel (c) shows the proportion of individuals from each colony that experienced conditions without twilight events (i.e., polar night and midnight sun) throughout the year. Dotted lines in (b) 


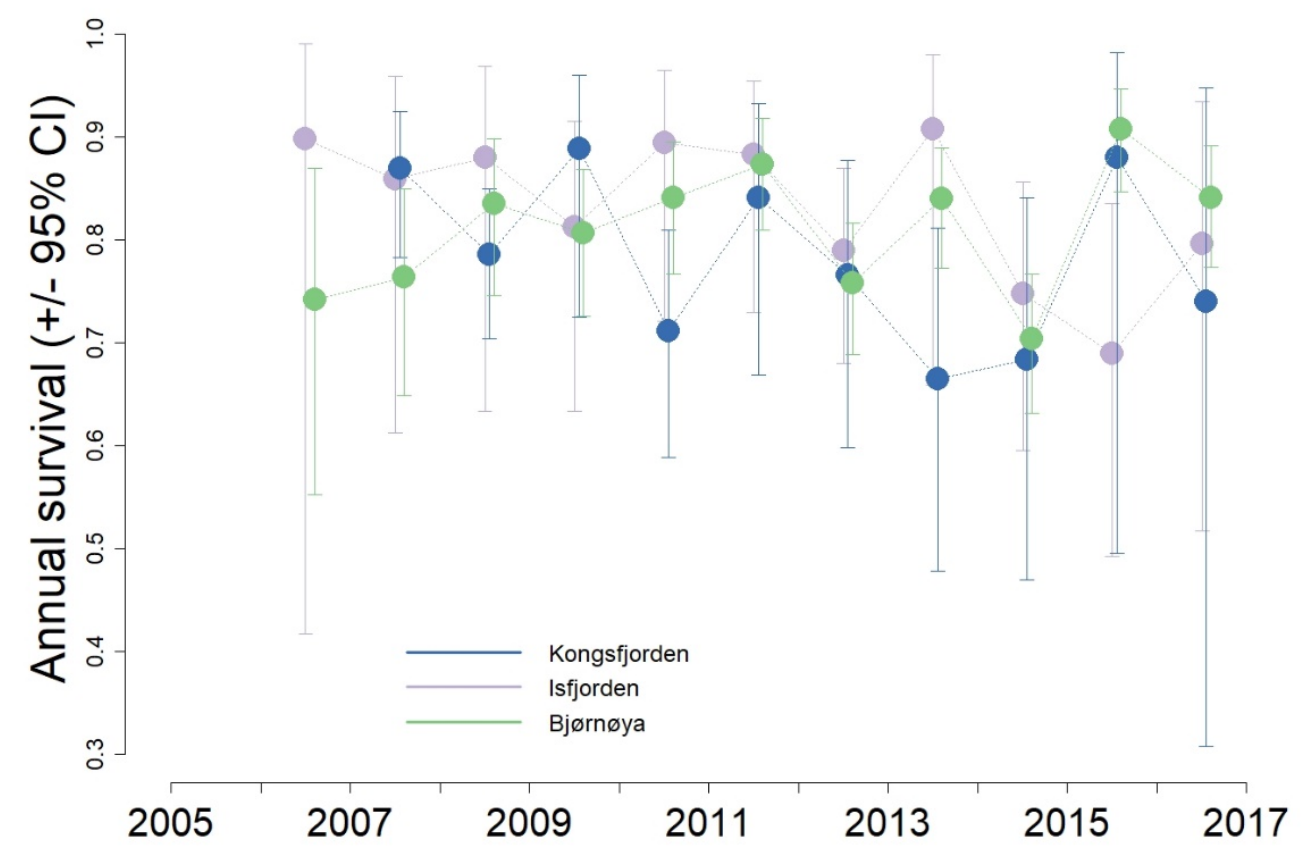

560

Figure 3. Annual survival ( $\pm 95 \%$ confidence intervals) of little auks breeding in Svalbard. Only the non-

563 transient groups have been considered (see details in Methods) and each survival estimate represents the 564 survival between two consecutive breeding seasons. Survival in the last year (2017-2018) cannot be 565 estimated separately from the recapture rate (Lebreton et al. 1992b). 